\title{
Paris/Berlim: ensaio de comparação entre os professores de duas universidades centrais'
}

Christophe Charle

\section{Resumo}

A partir da prosopografia comparada de duas amostras de professores de letras e de ciências das universidades de Paris e Berlim durante o mesmo período, este estudo situa essas duas elites universitárias em suas respectivas sociedades. A comparação das origens sociais dos professores e da sua evolução, do recrutamento geográfico, da formação escolar, e das dinâmicas de carreira permite apreender dois modelos bastante diferentes de meritocracia e dois processos distintos de evolução das comunidades universitárias. A centralização e a seleção elitista na França não impedem certa abertura social, ao passo que a descentralização e a inexistência de concursos formais continuam favorecendo os mesmos grupos dominantes na Alemanha. Apesar das intenções oficiais, evidencia-se a incapacidade de implantar o modelo germânico na França e, na Alemanha, de modernizar e democratizar o quadro de professores, mesmo com as tentativas da República de Weimar. As tensões crescentes que afetam os dois sistemas no período entre guerras, e as orientações sociais e políticas dominantes que opõem os dois grupos de professores, não podem ser, no entanto, reduzidas a um denominador comum de "crise", ao contrário são a prova das especificidades constitutivas de cada modelo universitário. Para além dos resultados empíricos, este artigo pretende defender a fecundidade heurística da combinação entre o método comparativo e a biografia social em escala europeia.

Palavras-chave: Paris. Berlim. Prosopografia comparada. Professores de letras e de ciências

O método prosopográfico teve um grande sucesso na história social há alguns anos atrás, notadamente para o estudo de elites universitárias. No entanto, tentativas de prosopografia comparada são raras e se restringem a alguns indicadores bastante limitados. A escolha por uma prosopografia

\footnotetext{
1 Publicado originalmente em: CHARLE, C. Paris/Berlin: essai de comparaison des professeurs de deux universités centrales, Histoire de l'éducation, $n^{\circ}$ 62, 1994, p. 75-109. Disponivel em: <http://www.persee.fr/doc/ hedu_0221-6280_1994_num_62_I_2734>. Tradução de Rodrigo da Rosa Bordignon. Agradeço a leitura e aos comentários de Christophe Charle e Odaci Luiz Coradini.

2 Professor de história contemporânea, Université Paris I-Panthéon-Sorbonne. E-mail: christophe.charle@ens.fr.
} 
comparada dos professores parisienses e berlinenses em um período de transição que vai dos anos 1870 a 1930 se justifica, portanto, de três modos. Primeiramente, pelo esforço em fundar empiricamente as hipóteses sociológicas levantadas ao final do Naissance des "intellectuels" (CHARLE, 1990, p. 231-232) sobre a diferenciação de situação social dos dois grupos no interior das elites dos dois países, e os efeitos ideológicos e políticos dessa diferença.

Em segundo lugar, a prosopografia comparada permite compreender, a partir de dentro, o funcionamento dos sistemas universitários e as inadaptaçóes crescentes que lhes caracterizam frente aos novos desafios encontrados pela universidade com a especialização da função de pesquisa e a diversificação disciplinar e social. O terceiro ponto a destacar é o esforço na busca de soluçóes para um conjunto de questóes metodológicas que incidem sobre toda comparação de um mesmo grupo em dois países diferentes. Esse problema já foi levantado por outros trabalhos, notadamente pela pesquisa coletiva dirigida por Jurgen Kocka sobre as burguesias europeias (KOCKA, 1988)3. A maior parte dos trabalhos comparativos contenta-se em retomar e colocar em paralelo pesquisas já realizadas, incorrendo em um duplo risco: aquele de interpretar mal os dados dos outros pesquisadores, e aquele de ser obrigado a reduzir o detalhe das informaçóes ao menor denominador comum. Do meu ponto de vista, isso acelera e arruína prematuramente as potencialidades do método comparativo em história social, expondo-o à crítica dos especialistas de cada país e, igualmente, aquela dos sociólogos que destacam as ingenuidades das comparaçóes mecânicas realizadas termo a termo. Mesmo se o esforço em conduzir a pesquisa de base para os dois países - com a necessidade, decorrente da escolha, de reduzir o número de indivíduos em análise -, municia-me contra os dois primeiros tipos de críticas, a escolha ingrata da erudição não me previne contra o último problema infantil do método comparativo, aquele do nominalismo. É prudente comparar termo a termo os professores da universidade de Paris e de Berlim? Em outras palavras, ocupariam eles uma posição exatamente análoga em seus sistemas universitários? Evidentemente, jamais se reduzirá um sistema policêntrico, mesmo que com um polo dominante, a um sistema centralizado com um polo hegemônico. No entanto, a dinâmica dos dois sistemas na época considerada reforça a opção escolhida. $\mathrm{O}$ sistema francês busca, por meio da

3 Ver comentário crítico, Charle (1990b). 
imitação do modelo alemão, reabilitar, precisamente nesta época, o centro e a periferia (WEISZ, 1983). Inversamente, o sistema alemão, na época em um contexto de unidade política, confere à Universidade de Berlim uma posição central que ela jamais havia tido até então. Um estudo mais geral realizado pelo geógrafo $\mathrm{H}$. $\mathrm{H}$. Blotevogel destacou, a partir de certo número de indicadores culturais, a polarização crescente por causa da hegemonia berlinense. O estudo das "demandas" dos universitários alemães de uma universidade para outra indica que Berlim tende a ocupar a posição de fim de carreira de todas as trajetórias, outras raras universidades, como Leipzig e Munique, podendo aparecer também como escolhas últimas de carreira, mas de forma cada vez mais excepcional. Enquanto entre 1871 e 1910, 85 professores berlinenses (da Universidade ou da Technische Hochschule) vieram de outra cidade, somente três saíram de Berlim para outras universidades. Para Leipzig, os números são respectivamente de 49 e oito, e para Munique de 32 e dois professores (BLOTEVOGEL, 1983, p. 151).

\section{Morfologia do conjunto}

O segundo elemento que pesa em favor da comparação é a similar relevância demográfica das duas populaçóes analisadas. A amostra alemã que serve de base para este estudo é composta de 74 professores ordinários das disciplinas científicas e de 110 das disciplinas literárias, todos pertencendo à Faculdade de Filosofia da Universidade de Berlim, entre 1870 e 1933. Ao contrário do modelo francês, na Alemanha as disciplinas científicas e literárias são agrupadas na Faculdade de Filosofia. Foram retidos apenas os professores que ensinaram por tempo significativo durante o período considerado na pesquisa, buscando incluir apenas aqueles que tem em Berlim um objetivo crucial, e não uma simples etapa da carreira. Um dos objetivos da comparação é isolar dois grupos de professores, um alemão e outro francês, que tenham chegado ao topo da consagração, o que na França se resume ao acesso a um cargo parisiense. A amostra francesa é constituída por professores com cargos em Paris entre 1879 e 1939, dos quais a biografia consta nos meus diferentes dicionários publicados, ou em estudos realizados paralelamente, mas não editados nos moldes prosopográficos ${ }^{4}$.

4 Cf. em particular meu artigo, Charle (1990c). 
O tamanho variável dessas populações, segundo as disciplinas e as universidades, já é um indicador interessante. Paradoxalmente, no país da ciência alemã, o número de titulares é menor nas disciplinas científicas do que na França, em períodos de duração comparáveis (63 anos para o primeiro, 60 para o segundo). Esse paradoxo se explica de duas formas: a inflação do estrato dos professores não catedráticos na Alemanha; a inexistência de separação entre as letras e as ciências, prejudicial à criação de cátedras científicas, uma vez que a maioria literária aumenta inconscientemente seu domínio; e enfim, a criação de estabelecimentos paralelos nos domínios científicos e tecnológicos: Technische Hochschule, de Charlottenburg, Landwirtschaftlische Hochschule, Physkalische-Technische Reichsanstalt, Kaiser-Wilhelm Gesellschaft, cujos institutos foram implantados em Dahlem a partir de 1911. Na França ao contrário, e em Paris em particular, mesmo se os estratos dos professores se diferenciam, a maior parte deles consegue subir na hierarquia, tendo em vista que novas cátedras são criadas para funções externas, mais fáceis de serem obtidas para as ciências do que para as letras, por causa dos argumentos de utilidade mobilizados. As Tabelas 1 e 2 permitem especificar essas consideraçôes gerais.

Tabela I - Evolução do número de cátedras literárias e científicas (professores ordinários) da Faculdade de Filosofia de Berlim

\begin{tabular}{cccc}
\hline Ano & $\begin{array}{c}\text { Disciplinas } \\
\text { literárias }\end{array}$ & $\begin{array}{c}\text { Disciplinas } \\
\text { científicas }\end{array}$ & Total \\
\hline 1870 & 20 & 7 & 27 \\
1880 & 23 & 13 & 36 \\
1890 & 37 & 13 & 50 \\
1900 & 42 & 17 & 59 \\
1909 & 48 & 22 & 70 \\
1928 & 47 & 32 & 76 \\
\hline
\end{tabular}

Fonte: Reinhard Riese: Die Hochschule auf dem Weg zum Wissenschaftlichen Grossbetrieb, Stuttgart, Klett, 1977, p. 355; Minerva, 1928. 
Tabela 2 -Evolução do número de cátedras literárias e científicas (professores) das Faculdades de Letras e de Ciências de Paris

\begin{tabular}{cccc}
\hline Ano & $\begin{array}{c}\text { Faculdade } \\
\text { de Letras }\end{array}$ & Faculdade de Ciências & Total \\
\hline 1860 & 15 & 18 & 33 \\
1880 & $16(+2)$ & $19(+2)$ & $35(+4)$ \\
1890 & $20(+3)$ & $20(+3)$ & $40(+6)$ \\
1901 & 25 & 25 & 50 \\
1928 & 42 & 49 & 91 \\
\hline
\end{tabular}

Fonte: Annuaire de l'instruction publique dos anos considerados e Minerva para 1928.

N. B.: Os números entre parênteses referem-se aos professores adjuntos,

assimiláveis aos professores titulares.

Constante no tempo, essa oposição deve ser compreendida, contudo, em razão de consideraçôes subsidiárias relativas à dinâmica das estruturas do ensino superior das duas capitais. Para que a comparação quantitativa tome verdadeiramente em conta o conjunto do ensino científico e literário, é necessário adicionar, para Paris, as cátedras do Collège de France, do Muséum e da École Polytechnique; e, para Berlim, aquelas da Technische Hochschule, assim como os postos dos institutos que gravitam em torno da Universidade. Encontramos aqui um dos limites intrínsecos das comparações de estruturas formalmente idênticas, mas diversificadas em razão de contextos institucionais variáveis. Lembremo-nos da quase igualdade dos dois grupos e da modernidade superior (em termos de ciência pura) da França. Como se explica a desvalorização permanente dos observadores franceses, contrastante com a autossatisfaçáo alemã, ou com o elogio geral dos observadores estrangeiros? Nesse ponto, é necessário colocar em pauta as pirâmides hierárquicas do conjunto dos sistemas nacionais e, sobretudo, os meios materiais postos à disposição dos professores.

Em um artigo célebre, Ferdinand Lot buscou, em 1904, fazer uma comparação caso a caso do conjunto dos professores das disciplinas literárias e científicas das universidades francesas e alemãs. Para Paris, ele alcança o número de 138 professores de letras de todos os tipos (compreendendo o Collège de France, a École du Louvre, a École pratique des Hautes Études, a 
École des beaux-arts, e o Conservatoire); e 125 para Berlim (compreendendo os privat-docenten ${ }^{5}$, o que é discutível tendo em vista que eles não são remunerados pelo Estado, situação inexistente na França, ao menos que se incluam os cursos livres). $\mathrm{O}$ ensino superior parisiense focalizado globalmente, para além das instituiçóes singulares, subclassifica o berlinense, ainda mais se excluímos os privat-docenten. Em contraposição, se compararmos o total nacional das universidades francesas e alemâs, a lacuna se amplia no sentido inverso, para além do desequilíbrio das populaçóes de estudantes dos dois países: 830 para a Alemanha, 354 para a França.

Uma situaçāo homóloga se encontra no domínio científico: Paris ultrapassa Berlim por 129 cargos contra 95 (sem a École Polytechnique), mas as universidades alemãs superam as francesas com 636 cargos contra 343 (LOT, 1906, p. 30-33, 58-61). Essa dupla assimetria fornece a chave da dinâmica dos dois sistemas. Apesar da polarização das carreiras berlinenses evocada anteriormente, o peso demográfico da universidade da capital do Reich permanece na mesma ordem de grandeza daquela das outras grandes universidades. Além disso, ela reúne $15 \%$ do conjunto dos estudantes alemães, enquanto de $1 / 3$ a metade dos estudantes franceses, dependendo das faculdades, encontram-se em Paris. A política francesa de reformas dos anos 1880 não conseguiu eliminar o desequilíbrio centro-periferia; faltaram uma massa crítica enraizada e um ambiente intelectual significativo, fornecidos para Paris pela galáxia de instituiçóes periféricas à Universidade. Entre os professores de literatura da maior universidade de província, Lyon, e aqueles da Faculdade de Letras de Paris, a relação é de quase 1 para 2 (28 contra 54); em ciências, é mais de 1 para 2 (50 em Paris, 23 em Lille). Na Alemanha, a diferença é menor: 69 para Leipzig contra 125 para Berlim em letras, $64 \mathrm{em}$ Bonn contra 95 em Berlim em ciências. É necessário analisar agora, quais são os efeitos sociais desses dados estruturais sobre as características dos professores.

5 No sistema alemão, designa os professores habilitados, mas sem cátedra ou cargo que garanta a remuneração por parte do governo. São autorizados a proferir cursos, conferências, etc., dos quais obtém ganhos por meio das taxas de específicas (N. T.). 


\section{Origens sociais}

A comparação das origens sociais pode ser abordada de três pontos de vista:

1. Como um indicador da posição social de um grupo profissional na estrutura social global.

2. Como sinônimo da abertura relativa das elites universitárias, já que a Faculdade de Filosofia na Alemanha e as Faculdades de Letras e de Ciências na França ocupam uma posição homologamente intermediaria e/ou dominada no conjunto do sistema universitário e, mais globalmente, no campo das elites sociais.

3. Diacronicamente e tematicamente, enfim: o recrutamento social dos professores universitários de acordo com a época e o conjunto de disciplinas varia em que sentido?

Antes de responder a essas três questóes, convém passar para uma etapa anterior, aquela da reflexão metodológica sobre as codificaçôes utilizadas, as quais nunca serão ideais, mas para as quais os vieses devem ser registrados para ponderar os resultados obtidos.

A primeira questão remete ao debate recorrente sobre as codificaçóes socioprofissionais, notadamente por ser difícil aplicar um esquema uniforme sobre uma sociedade não unificada e em rápida transformação, como na época considerada. Quando se pretende aplicar a mesma divisáo sobre duas sociedades, elas mesmas diferentes, colocamo-nos diante de sérias objeçôes dos especialistas. A única resposta para esse debate, na realidade sem saída, é uma opção pragmática. Faz-se necessário recorrer a diversos esquemas concorrentes em razão dos critérios complementares e considerando o problema em questão: uma codificação sintética, uma versão da codificação já utilizada para a pesquisa sobre as elites da republica ${ }^{6}$, e codificaçôes parciais para este ou aquele critério (vínculo com o Estado, com a antiga nobreza, e com a cultura dominante) que ganham sentido particular para cada contexto nacional, sem esquecer, para fins de controle, a transcrição

6 Cf. Charle (2006). (N.T) 
o mais fiel e próxima possível das fontes das profissóes dos pais. Evitamos assim de reificar categorias muito gerais que, na realidade, se sobrepóem, e de criar falsas analogias ao aplicá-las mecanicamente.

É correto, no entanto, retomar uma codificação de base francesa e aplicá-la ao caso alemão? A própria prática de codificação da pesquisa em curso convida a responder positivamente. Apoiando-se sobre as classificaçóes bastante detalhadas dos historiadores alemáes da mobilidade social, não tropeçamos em incongruências maiores, devendo as incertezas muito mais aos limites das fontes do que do código em si. As únicas categorias problemáticas - o que ocorre também na França - foram os dois grupos da burguesia econômica: grande burguesia e média burguesia. Como na França, os termos "negociante" ou "proprietário", os vocábulos alemães Kaufmann ou Privatier não possuem, sem índices suplementares, uma hierarquia incontestável entre os dois níveis definidos. A probabilidade estatística indica que a maioria pertence, sobretudo, ao estrato inferior, mas esse raciocínio global não resolve as questóes individuais, sob pena de decretar arbitrariamente a repartição que buscamos precisamente estabelecer. No caso da França, foi possível, em geral, precisar a clivagem apoiando-se em informaçóes fiscais. Para a Alemanha, a pesquisa está basicamente fundada sobre informaçóes impressas, sendo difícil chegar a uma certeza comparável. Ao contrário, para todos os outros grupos, a correspondência com os homólogos franceses é bastante simples, mesmo se as hierarquizaçóes internas mais finas nos escapam. A padronização de classificaçóes é uma necessidade de todo estudo de elite, sob pena de haver demasiadas categorias, que reúnem apenas casos individuais.

A segunda questão remete ao problema da homogeneidade das disciplinas representadas no interior das faculdades francesas e alemás comparadas. A questão se coloca, sobretudo, para o período mais recente, quando a diferenciação disciplinar não evolui no mesmo ritmo, nem exatamente sobre as mesmas bases nos dois países. Algumas disciplinas alemãs, como as Staatswissenschaften ${ }^{7}$, têm seus equivalentes nas faculdades de direito

\footnotetext{
No caso Francês, as disciplinas que comporiam o equivalente às "ciências de estado" ou à ciência política alemã tiveram espaço em duas instituições de natureza distinta: a École Libre des sciences politiques, instituição privada fundada em I87 I, e a Faculdade Direito de Paris. A afirmação da ciência política enquanto disciplina específica e com pretensões de especialização só ocorreria nos anos 1940, com a nacionalização da École Libre des sciences politiques e a criação da École nationale d'administration (N. T.).
} 
francesas; igualmente, o ensino de estética ou arqueologia são muito menos desenvolvidos na França, presentes, sobretudo, nas grandes instituiçôes. Enfim, outras disciplinas, como a geografia, unificadas na França, estáo divididas entre as letras e as ciências na Alemanha, de acordo com a especialidade humana ou física. Seria possível multiplicar os exemplos.

Para eliminar essas distorçôes e seus efeitos sociais, precisaríamos, com todo rigor, acrescentar, às cátedras das faculdades parisienses consideradas, ao menos àquelas do Collège de France, o que reduziria o descompasso, mas aumentaria o desequilíbrio entre as bases estatísticas das duas amostras. Optamos por explicitar o problema e utilizar testes estatísticos secundários para corrigir os vieses, ao invés de tornar ainda mais arbitrária a correspondência dos dois grupos de universitários.

A última questão conecta-se aos pontos precedentes e permite modulá-los. Já se dispóem de algumas indicações com base nos trabalhos de Fritz K. Ringer e de Konrad H. Jarausch (RINGER, 1969 [2000], JARAUSCH, 1982), os quais permitem prever uma resposta globalmente negativa para a Alemanha. Uma aposta segura é que a Faculdade de Filosofia de Berlim, considerando o grau elevado de seleção que representa o acesso às suas cátedras, reforçará, ao invés de invalidar esses indicadores. Igualmente, meu estudo diacrônico e temático sobre a amostra francesa evidenciou diferenças sistemáticas entre as faculdades de letras e de ciências, bem como uma abertura social real, mas tardia, do recrutamento, e em ritmos variados segundo as faculdades. A hipótese de trabalho que se pode formular a partir dessas indicaçóes gerais é a de uma diferença crescente da lógica de reprodução dos dois sistemas universitários e de suas faculdades principais.

\section{Os professores entre as elites}

Quanto menos uma categoria de elite é seletiva em seu recrutamento, menos sua posição é elevada no interior das elites. Essa lei geral implica, examinando a Tabela 3, que os professores da Faculdade de Filosofia de Berlim em seu conjunto ocupam uma posição evidentemente superior àquela de seus homólogos franceses. A pesquisa suplementar na qual se baseia a visão geral situada no final do Naissance des "intellectuels" reforça as hipóteses propostas. Enquanto a categoria mais baixa da codificação 
representa somente de $7 \%$ a $10 \%$ do conjunto das origens sociais em Berlim, a proporção é de duas a três vezes mais em Paris, principalmente quanto mais se avança no tempo e quanto mais se aproxima do polo científico das elites universitárias. Tal diferença ultrapassa largamente a margem de erro de toda codificação uniformizadora. Além disso, as categorias superiores, que são sobre-representadas do lado berlinense, são subrepresentadas do lado francês, o que reforça essa primeira diferença. Assim, o grupo profissional menos incerto por sua posição superior na sociedade dos dois países, aquele dos funcionários de alto escaláo e das elites políticas, direcionou poucos de seus filhos para uma carreira de ensino superior na França: ao todo oito professores da Sorbonne sobre 277 vêm de uma família de grandes funcionários ou políticos $(2,8 \%)$, e somente da segunda geração, ou seja, quando as carreiras universitárias foram revalorizadas pela República. Na Faculdade de Filosofia de Berlim, ao contrário, 16 professores sobre 175 são provenientes dessa elite, ou seja, próximo de 10\%. Igualmente, a grande burguesia econômica estabelece, na Alemanha, uma distância menor frente às carreiras universitárias (9,8\% considerando todas as disciplinas), contra menos de 3\% nas faculdades parisienses. Para a média burguesia econômica, os índices são bastante similares tanto em Berlim, quanto em Paris: respectivamente $18,5 \%$ (ciências) e $20 \%$ (letras), contra 22,2\% (ciências) e 20,6\% (letras). Em cada país, os resultados indicam a função de enobrecimento cultural da universidade para todas as famílias sem grande capital cultural e recém-chegadas à classe dominante. Notaremos, no entanto, que os índices franceses são superiores, principalmente no polo científico, fileira de promoção por excelência dos recém-chegados em decorrência do menor peso da cultura humanista ${ }^{8}$. A similitude das taxas de filhos de membros das profissôes jurídicas e de frações intelectuais não deve, também, induzir ao erro. É aqui que a análise mais fina da composição das fraçóes torna-se indispensável. Enquanto que, em Paris, os descendentes das fraçôes intelectuais são essencialmente filhos de professores do secundário, em Berlim, ao lado dos filhos de médicos, de pastores e de professores, estão também os herdeiros em sentido pleno, uma vez que encontramos 24

8 Neste grupo incluimos, para Berlin, os pais dotados, apesar de tudo, de um certo capital cultural: entre os professores das disciplinas literárias, um engenheiro de estradas de ferro, dois farmacêuticos, dois comerciantes de arte, um tipógrafo, e um doutor em engenharia. 
filhos de professores universitários sobre 175 (13,1\%), taxa de reprodução que representa mais que o dobro da francesa: 15 sobre 277 (5,4\%).

Como já demonstramos em outros estudos, com exceção das ciências no período recente e dos grandes estabelecimentos (CHARLE, 1987, p. 339-341; CHARLE, 1988), a permanência das dinastias universitárias na França, índice ao mesmo tempo de forte espírito de corpo, de autocontrole do recrutamento e da consciência de ocupar uma posiçáo de elite que não tem nada a invejar das outras, é um fenômeno marginal, enquanto na Alemanha, e principalmente em Berlim, ela resiste às transformaçôes morfológicas. A mesma seletividade social superior se encontra no interior das profissóes jurídicas. Em Berlim, elas estão majoritariamente ligadas à magistratura, portanto socialmente mais elevadas ${ }^{9}$, enquanto que em Paris, trata-se, sobretudo, de juristas liberais, dos quais uma parcela está em declínio, símbolo da retração da burguesia tradicional frente a uma carreira na qual a concorrência é cada vez mais severa. A última categoria de origem ainda não analisada, aquela dos filhos de funcionários de médio escalão, evolui pouco no interior das duas amostras de professores, tanto em letras como em ciências, e para todas as épocas: de 9\% a 15\% dos professores. Evidentemente, seria necessário dispor de dados globais para determinar se esta analogia náo decorre de uma ilusáo criada pela codificação. Tanto na França quanto na Alemanha, a estagnação desse grupo significa, na realidade, uma regressão relativa, já que se trata de funcionários cujo peso aumenta na sociedade global e que se beneficiam, geralmente, de auxílios particulares para facilitar os estudos de seus filhos.

Considerando essa primeira aproximação, aparentemente os professores da Faculdade de Filosofia de Berlim estão mais próximos das frações superiores da classe dominante que os professores de Paris. A carreira universitária está bem mais conectada às elites do que na França, onde ela faz parte dos modos de promoçáo das fraçóes intermediárias da burguesia, notadamente daquelas próximas ao polo cultural, ou mesmo de alguns elementos superselecionados dos grupos dominados. Esses últimos são muito mais raros em Berlim: contamos 12 sobre 175 (6,8\%), para um conjunto que constitui $70 \%$ a $80 \%$ da população do país. Essa diferença remete à menor continuidade entre as fileiras do secundário e do superior na Alemanha, a maior exigência de mobilidade entre as carreiras para ingressar

9 Cf. Rottleuthner (1988). 
nas redes de cooptação, ao desequilíbrio crescente entre o número de posiçôes precárias e definitivas no interior da universidade alemã e, enfim, ao malthusianismo conservador alemão que marca o fim do século XIX frente à superprodução de diplomados, em oposição à ideologia oficial de promoção social defendida pelo sistema escolar francês.

Tabela 3 - Origens sociais comparadas dos professores parisienses e berlinenses (letras e ciências) (1870 - 1930)

\begin{tabular}{lcccc}
\hline & Paris & Berlim & & \\
\hline CSP do pai & Letras & Ciências & Letras & Ciências \\
\hline Grande burguesia & 4,24 & 2,56 & 6,6 & 14,3 \\
$\begin{array}{l}\text { Funcionários de } \\
\text { alto escalão e elites }\end{array}$ & 2,42 & 3,42 & 11,4 & 5,7 \\
políticas & & & & \\
Média burguesia & 20,6 & 22,2 & 20 & 18,5 \\
Profissões jurídicas & 4,24 & 2,56 & 8,5 & 8,6 \\
Frações intelectuais & 34,5 & 23,93 & 36,2 & 28,5 \\
Funcionários de médio & 11,5 & 10,25 & 9,5 & 14,3 \\
escalão & & & & 10 \\
Pequena burguesia & 22,4 & 35 & 7,6 & $70^{*}$ \\
$\mathrm{~N}$ & $165^{*}$ & $119^{*}$ & $105^{*}$ & \\
\hline
\end{tabular}

Nota: * Não respostas excluídas.

Fonte: Elaborada pelo autor

\section{Indicadores de status}

A intensa proximidade entre os professores berlinenses e as fraçóes sociais dominantes é confirmada e especificada graças a uma análise sintética das origens sociais em razão de três elementos de status que marcam as clivagens entre as duas sociedades consideradas: o pertencimento à função pública, a posse de uma cultura universitária pelo pai, e, enfim, o pertencimento à nobreza. Enquanto na França o último indicador praticamente desapareceu do mundo universitário depois de 1860, salvo casos incomuns, isso não ocorre exatamente no mesmo sentido no corpo 
professoral da capital da Prússia. A obtenção de títulos honoríficos integrando os professores no interior da nobreza de função continua um costume corrente - e acionado pelos interessados -, enquanto que os autênticos nobres não desdenham a obtenção de uma cátedra: $10 \%$ em letras e $8 \%$ em ciências enquadram-se nesse caso (incluindo as não respostas). Contudo, são os dois outros indicadores (que resumem o termo alemão Bildungsburgertum) que tornam mais evidente a função social do corpo professoral enquanto instância de reprodução dos grupos dirigentes, bem como sua integração aos últimos. Ao contrário, as porcentagens inferiores na França, e principalmente em ciências, provam a posiçáo mais marginal dos professores parisienses com relação ao pertencimento a nobreza.

Tabela 4 - Indicadores de status dos professores parisienses e berlinenses

\begin{tabular}{lcccc}
\hline Berlim & Paris & & & \\
\hline & Letras & Ciências & Letras & Ciências \\
\hline Pai em função pública & 52,3 & 54,2 & 41,7 & 34,5 \\
$\begin{array}{l}\text { Pai com ensino } \\
\text { superior }\end{array}$ & 50,9 & 50 & 32,5 & 23,9 \\
Pai nobre & 10,1 & 8 & & \\
\hline
\end{tabular}

Fonte: Elaborada pelo autor

Independentemente da diferença entre as nações, observa-se também uma distinção transversal segundo a ordem das faculdades. Excetuando-se a tradição de serviço público (e ainda, para Berlim, a diferença é pequena), todos os indicadores de status superior estão concentrados na França e na Alemanha, do lado literário: entre os pais dos professores de letras berlinenses e parisienses, encontra-se um maior número de possuidores de forte capital escolar, já em Berlim destacam-se os provenientes de famílias nobres, e mais funcionários em Paris. Já que no conjunto das faculdades encontram-se homologias, essa hierarquização geral em termos de status comum aos dois países remete à estruturação social antiga das universidades, ainda não superada na época 
considerada $^{10}$. O hiato é, contudo, menos forte na Alemanha do que na França, isso se deve inexistência de separação entre as faculdades e a seletividade social mais forte das carreiras universitárias na Alemanha. $\mathrm{Na}$ França, essa divisão oficial favorece às derivaçóes autônomas dos mecanismos de cooptação que acentuam as diferenças entre os perfis sociais dos professores.

\section{Evolução}

A homologia estrutural entre os dois países no plano das disciplinas caminha em paralelo com uma divergência crescente em termos de evolução do recrutamento. A política voluntarista de reforço das faculdades literárias e científicas sob a República conduziu, como mostram as tabelas a seguir, a uma abertura social, principalmente para as classes médias e para a pequena burguesia, mais rápida em ciências, mas igualmente sentida em letras no período entre guerras. Os professores berlinenses, apesar do crescimento comparável do número de cátedras e da melhoria das possibilidades de carreira durante a República de Weimar, não conhecem, no entanto, uma evolução similar. Sem dúvida existe, tanto em letras como em ciências, uma regressão da dominação do Bildungsburgertum (fenômeno encontrado igualmente no âmbito do recrutamento dos estudantes), mas isso não favorece a pequena burguesia ou as classes médias, mas acima de tudo os herdeiros da burguesia econômica. Logo, em ciências e em letras, os herdeiros de um importante ou médio capital econômico dobram globalmente sua proporção, respectivamente de $21,1 \%$ para $41,6 \%$ e de $18 \%$ para $33,9 \%$. Essa evolução, que poderíamos considerar como obra do acaso, tendo em vista o baixo número dos efetivos considerados, é paralela àquela do conjunto dos professores alemães", e da necessidade

10 Esta constância encontra-se na amostra de C. von Ferber (1956), em minha amostra sobre o conjunto de instituições de ensino superior parisienses em 190 I (CHARLE, 2006), nos dados sobre estudantes fornecidos por Titze, e até mesmo nos dados recentes de Bourdieu (1984) para os professores parisienses de 1967.

II Cf. F. K. Ringer (1988, p. 96-99): os filhos de diretores de empresas, negociantes e diretores administrativos passam, no plano global, de 16 para 28\% (periodo 1860-1889 e 1890-1919), depois para 31\% (1920-1933). As incertezas da classificação não permitem tomar esses números por seu valor em nominal e independente de sua similitude com meus achados. $O$ importante é a tendência convergente. A inexistência de democratização 
experimentada nos estratos da nova burguesia econômica, impulsionada pela industrialização, de dotar seus filhos dos índices de status cultural das fraçooes tradicionais da burguesia. Em ciências, pode se tratar, ao mesmo tempo, de uma estratégia prática, considerando que os que não têm sucesso na pesquisa serão aproveitados nas empresas. Assim, alguns grandes químicos alemães iniciaram pelos estudos técnicos na perspectiva de seguir carreira na empresa da família, antes de se orientar em direção à pesquisa universitária. Pode-se citar, aqui, a trajetória de Ernst Otto Beckmann. Filho de um inventor, fundador de uma tinturaria em Solingen, começa como estagiário em uma farmácia, torna-se farmacêutico e depois prossegue seus estudos de química em Leipzig, onde defende sua habilitaçáo e inicia então uma carreira de pesquisa em química aplicada, a qual o conduzirá à direção de um instituto da Kaiser-Wilhelm Gesellschaft em Dahlem, e a uma cátedra Unter den Linden ${ }^{12}$.

Tabela 5 - Evolução das origens sociais dos professores (letras e ciências) de Paris e Berlim

\begin{tabular}{lcccc}
\hline Origem social & Paris & & & \\
\hline & Letras & Ciências & & \\
\hline & $\mathbf{1 8 7 9 - 1 9 0 8}$ & $\mathbf{1 9 0 9 - 1 9 3 9}$ & $\mathbf{1 8 7 9 - 1 9 0 8}$ & $\mathbf{1 9 0 9 - 1 9 3 9}$ \\
\hline Grande burguesia & 6,9 & 2,8 & 2,2 & 2,7 \\
Funcionários de & - & 3,7 & - & 5,4 \\
alto escalão e elites & & & & \\
políticas & 18,9 & 21,5 & 34 & 15 \\
Média burguesia & 8,6 & 1,8 & 4,5 & 1,3 \\
Profissões jurídicas & 34,4 & 34,5 & 25 & 23,2 \\
Frações intelectuais & 12 & 11,3 & 9 & 9,5 \\
Funcionários de médio & & & & \\
escalão & 18,9 & 23,5 & 22,7 & 42,4 \\
Pequena burguesia & $58^{*}$ & $107^{*}$ & $44^{*}$ & $73^{*}$ \\
$\mathrm{~N}$ & & &
\end{tabular}

é igualmente evidente mesmo para uma amostra nacional e transdisciplinar, podendo ser imputada ao caráter conservador e seletivo da Universidade de Berlin.

12 Neue Deutsche Biographie, I, p. 725; Wer ist's. 1909. 


\begin{tabular}{|c|c|c|c|c|}
\hline Origens sociais & Berlim & & & \\
\hline & Letras & Ciências & & \\
\hline & $1870-1908$ & 1909-1930 & $1870-1908$ & $1909-1930$ \\
\hline Grande burguesia & 6 & 7,2 & 9 & 18,9 \\
\hline $\begin{array}{l}\text { Funcionários de } \\
\text { alto escalão e elites } \\
\text { políticas }\end{array}$ & 8 & 14,5 & 6 & 5,4 \\
\hline Média burguesia & 12 & 27,2 & 12,1 & 24,3 \\
\hline Profissões jurídicas & 8 & 9 & 15,1 & 2,7 \\
\hline Frações intelectuais & 46 & 27,2 & 33,3 & 24,3 \\
\hline $\begin{array}{l}\text { Funcionários de médio } \\
\text { escalão }\end{array}$ & 10 & 9 & 12,1 & 16,2 \\
\hline Pequena burguesia & 10 & 5,4 & 12,1 & 8,1 \\
\hline $\mathrm{N}$ & $50^{*}$ & $55^{*}$ & $33^{*}$ & $37^{\star}$ \\
\hline
\end{tabular}

A partir das especificidades históricas da universidade alemá, podemos é possível, igualmente, avançar em uma interpretação complementar para dar conta dessa inexistência de abertura social. O primeiro grupo observado fez seus estudos em uma conjuntura relativamente favorável, o que permitiu a alguns elementos de origem modesta de vislumbrar a expectativa de uma carreira de ensino superior, e mesmo de obter um cargo, independentemente das barreiras sociais. Ao contrário, o segundo grupo se lança ao ensino superior no momento de crescimento do hiato entre o topo e a base da hierarquia universitária, mesmo quando o número de postulantes potenciais aumenta com a escolarização secundária e superior crescentes. Em 1860, existiam 107 privat-docenten nas faculdades de filosofia das universidades prussianas, para 81 cargos de professor extraordinário e 175 cargos de professor ordinário, ou seja, uma possibilidade plausível de mudar de estatuto rapidamente depois do término dos estudos superiores nestes anos, o que caracteriza a situação do primeiro grupo. Em 1889/1890, a situação se degradou significativamente: 172 privat-docenten (65 a mais), 154 professores extraordinários (73 a mais), para 284 professores ordinários (109 a mais), o que significa um déficit de 29 cargos; 20 anos mais 
tarde (1909), o malthusianismo oficial se agrava sem, no entanto, desencorajar os aspirantes às cátedras: contamos 332 privat-docenten, quase tão numerosos quanto os professores ordinários (344), enquanto 172 professores extraordinários esperam seu espaço: o déficit passou, então, para 160 cargos (TITZE, 1990, p. 147). Nessas condiçóes, compreendemos que os jovens doutores com menores possibilidades de esperar para se tornar titular com os rendimentos miseráveis ou aleatórios, voltam-se para as carreiras mais modestas, mas mais certas, do ensino secundário em letras, ou dos cargos no setor privado para as ciências: os anos 1900 correspondem, precisamente na Alemanha, a um novo boom econômico e ao aumento da necessidade de professores no ensino secundário ${ }^{13}$. Mesmo que os dados morfológicos não fossem claramente percebidos pelos recém-chegados, alguns sinais ideológicos ou sociais eram evidentes: o movimento dos nicht-ordinarien que traduz o descontentamento frente à lentidão das carreiras daqueles que já possuem cargos, os debates sobre o modo de retribuição dos professores, objeto de reformas e de artigos na imprensa que mostram as grandes desigualdades, sem falar do debate recorrente sobre a superprodução de diplomados, da qual uma das funçóes, como demonstrou H. Titze, é desencorajar os estudantes de origem modesta, o que contribui para reestabelecer o equilíbrio do ciclo universitário por meio de uma desilusão prévia.

\section{Origens geográficas e estudos}

A comparação dos indicadores geográficos, que permitem definir as trajetórias dos professores das duas universidades, chega a conclusóes inversas daquelas obtidas por meio da análise do seu recrutamento social. Isso remete à estruturação geográfica específica dos dois espaços universitários e preenche, igualmente, uma função comparativa. Tendo em vista que os professores ordinários se caracterizam por uma forte homogeneidade social e uma grande proximidade familiar de suas

13 Entre 1895 e 1910, passamos de 5.814 cargos de professores permanentes do secundário na Prússia para 10.258 (TITZE, 1990, p. 150). Sobre a expansão econômica da Belle Époque, ver Nipperdey (1991, p. 252, 27 I). Sobre o aumento do salário dos engenheiros do setor privado, ver Kocka (1979, p. 85-100) e Jarausch (1990, p. 17-22). 
futuras funções, eles podem se dispensar de uma socialização precoce na capital da Prússia. Sem dúvida, os berlinenses de nascimento estão sobrerrepresentados em relação ao peso demográfico da capital $(8,9 \%)$, uma cidade que representa na metade do século XIX menos de $2 \%$ da população alemá (entre 500.000 e 1 milhão de habitantes para 40 a 50 milhóes no Reich). Mas essa vantagem de nascimento não é similar àquela da qual se beneficiam os parisienses, originariamente encravados na Sorbonne (entre 17,7 e $36,3 \%$ segundo o período e a faculdade), para uma cidade reunindo $3 \%$ da população francesa. Se acrescentarmos a esse primeiro indicador àquele dos estudos superiores total ou parcialmente realizados nas duas capitais consideradas, a Terceira República, apesar de sua política descentralizadora, está longe de se igualar a circulação acadêmica alemã. Sem estudos em Paris, praticamente não há chances de acessar uma cátedra parisiense, a melhor prova disso é que os raros casos de estudos iniciais na província são sempre completados por estudos em Paris. Em Berlim, uma maioria dos futuros professores estão no mesmo caso, mas raramente trata-se de estudos unicamente berlinenses e isso não exclui de modo definitivo aqueles formados em outro país, como na França. Esse indicador estatístico não é apenas a tradução biográfica da parte significativa de estudantes formados em Paris relativamente ao total nacional, tendo em vista que o desequilíbrio é muito mais acentuado. Ele manifesta, sobretudo, a existência de uma rede de pré-recrutamento geográfico, passando principalmente pela École Normale Supérieure, de onde a maioria dos professores é proveniente (em declínio em letras, em ascensão nas ciências). Além disso, essa via real é reforçada pela aprendizagem dos não normaliens ${ }^{14}$ nos laboratórios e/ou em associação aos mestres da Sorbonne. As duas fileiras constituem um espaço de homogeneização que compensa a maior heterogeneidade de origem social dos aspirantes sorbonnards quando comparados aos ordinarien berlinenses. Socializados no interior de famílias em sua maioria ligadas ao Estado ou à Universidade, a elite dos professores alemães pode ter origens locais ou lugares de formaçáo mais diversos em nome dos Lern - e Lehrfreiheit humboldtianos, destinados de maneira explicita à "boa sociedade".

14 Ex-alunos da École normale supérieure (N.T.). 
A homogeneidade do meio universitário alemão é assegurada por um duplo fenômeno de barreiras sociais invisíveis e de fluxos cruzados permanentes entre os diversos pontos do sistema, tanto de professores como de estudantes. Ela autoriza, entáo, uma maior indeterminação dos percursos intermediários. Na França, ao contrário, as fortes desigualdades de valor e função das faculdades centrais e periféricas, assim como a existência de caminhos mais rápidos de promoção intelectual, balizam percursos quase obrigatórios de mobilidade.

Essas práticas eletivas iniciais induzem relaçôes psicológicas com a carreira fortemente contrastadas, salvo quando o meio de origem na França se aproxima sensivelmente do meio dominante na Alemanha: vocação e autoformação (Bildung) na Alemanha, espírito de competição e de conformidade na França, o que induz aos concursos sucessivos. A minoria atípica que escapa disso na França, se se aproxima do tipo-ideal alemão (aristocratismo ao menos), não pode esquecer a posição dominante ocupada pelos professores dotados de atributos adequados aos valores centrais do sistema francês.

Tabela 6 - Lugar de estudos superiores dos professores parisienses e berlinenses ( $\%$ na coluna)

\begin{tabular}{lcc}
\hline Estudos superiores em Berlim & Letras & Ciências \\
\hline 1879-1908 & 48,1 & 65,7 \\
1909-1930 & 68,4 & 35 \\
Conjunto do período & 58,5 & 49,3 \\
\hline Estudos superiores em Paris & & \\
\hline 1879-1908 & 94,6 & 88,6 \\
1909-1929 & 82,8 & 85,7 \\
1930-1939 & 85,3 & 96,7 \\
\hline
\end{tabular}


Tabela 7 - Tipologia das localidades de nascimento dos professores parisienses e berlinenses

(\% na coluna)

\begin{tabular}{|c|c|c|c|c|}
\hline $\begin{array}{l}\text { Tipo de cidade de } \\
\text { nascimento }\end{array}$ & Berlim & & & \\
\hline & Antes de 1909 & 1909 ou depois & & \\
\hline & Letras & Ciências & Letras & Ciências \\
\hline Berlim & 3,7 & 8,6 & 14 & 10 \\
\hline Outra capital* & - & 2,8 & 8,8 & 10 \\
\hline Cidade universitária & 24 & 34,3 & 8,8 & 17,5 \\
\hline Outra cidade & 44,4 & 31,5 & 42,1 & 40 \\
\hline \multirow[t]{4}{*}{$\begin{array}{l}\text { Interior ou cidade } \\
\text { mercantil }\end{array}$} & 27,8 & 22,8 & 26,3 & 22,5 \\
\hline & Paris & & & \\
\hline & Antes de 1909 & 1909 ou depois & & \\
\hline & Letras & Ciências & Letras & Ciências \\
\hline Paris & 33,3 & 36,3 & 17,7 & 22,5 \\
\hline Cidade universitária & 10,5 & 15,9 & 16,8 & 14 \\
\hline $\begin{array}{l}\text { Cidade sede de } \\
\text { administração } \\
\text { (Préfecture) }\end{array}$ & 14 & 13,6 & 21,5 & 11,2 \\
\hline Oura cidade & 26,3 & 20,4 & 21,5 & 28,1 \\
\hline $\begin{array}{l}\text { Interior ou cidade } \\
\text { mercantil }\end{array}$ & 15,7 & 20,4 & 21,5 & 28,1 \\
\hline
\end{tabular}

Nota: * Viena, São Petesburgo.

\section{$O$ reconhecimento $e$ a ascensão}

\section{Duas lógicas de promoção: remuneração}

Como todos os indicadores precedentes àquele das remuneraçóes pode ser tomado como um índice de posiçáo no interior das elites. Em termos de médias e de diferenças hierárquicas (entre o início e o final da carreira, ou entre as universidades de início ou de final da vida), os universitários franceses e alemães, se colocamos a parte por um instante a questão 
dos adicionais anexos à remuneração, situam-se em níveis muito similares, com uma pequena vantagem da Sorbonne sobre os professores berlinenses "médios", na medida em que as obrigaçóes de serviço são mais leves em Paris. Os protestos persistentes na França, principalmente nos anos 1900, têm conotação distinta daqueles na Alemanha, onde o debate refere-se sobretudo à repartição dos adicionais.

Tabela 8 - Escala das remunerações na França e na Prússia em torno de 1900 (em francos da época)

\begin{tabular}{lcc}
\hline Universidade & Início da carreira & Máximo \\
\hline Paris & 12.000 & 15.000 \\
França, província & 6.000 & 12.000 \\
Berlim & $8.980+$ adicionais & $11.930+$ adicionais \\
Prússia, província & $5.160+$ adicionais & $8.100+$ adicionais \\
\hline
\end{tabular}

Fontes: Bornecque (1911, p. 296-331, tabela p. 314).

Nota: Os números precedentes representam o total bruto em francos, sem os adicionais anexos diversos, algumas vezes muito importantes na Alemanha.

Devemos ver, então, a expressão de um descompasso nas remuneraçóes francesas, mesmo revalorizadas em relação à hierarquia geral dos rendimentos dos funcionários superiores? A comparação das pirâmides da remuneração média e superior na Prússia e na França nos anos 1890-1910 indica que não é o caso (Tabelas 9 e 10).

A diferença das remuneraçóes dos professores de Berlim se situa um pouco acima dos vortragende Räte (equivalente aos chefes de divisão franceses), e representa mais que o dobro da remuneração dos professores do secundário. 


\section{Tabela 9 - Situação dos professores universitários prussianos na hierarquia dos salários dos funcionários da Prússia (em marcos correntes e equivalentes em francos da época)}

\begin{tabular}{|c|c|c|}
\hline Categoria & 1890 & 1910 \\
\hline Ministro & $36.000 \mathrm{M}(45.000 \mathrm{~F})$ & $36.000 \mathrm{M}$ \\
\hline Sub secretário de Estado & $\begin{array}{c}15.000 \mathrm{M}(+1.500 \text { de auxílio } \\
\text { moradia })(18.750 \mathrm{~F})\end{array}$ & $\begin{array}{c}20.000 \mathrm{M}(+2.100 \text { de auxílio } \\
\text { moradia })\end{array}$ \\
\hline Diretor & $\begin{array}{c}15.000 \mathrm{M}(+1.500 \text { de auxílio } \\
\text { moradia })(18.750 \mathrm{~F})\end{array}$ & $14.000-17.000 \mathrm{M}(+2.100)$ \\
\hline Vortragende Räte & $\begin{array}{l}7.500-9.900 \mathrm{M}(+1.200) \\
\quad(9.375-12.375 \mathrm{~F})\end{array}$ & $\begin{array}{c}7.000-11.500 \mathrm{M}(+1.680)(8.750 \\
-14.375 \mathrm{~F})\end{array}$ \\
\hline $\begin{array}{l}\text { Professores ordinários de } \\
\text { Berlim, média }(1896)^{\star}\end{array}$ & $6.000(+900)(7.400 \mathrm{~F})$ & $6.735-8.950 \mathrm{M}(8.980-1 \mathrm{I} .930 \mathrm{~F})$ \\
\hline $\begin{array}{l}\text { Professores ordinários da } \\
\text { Prússia, média }(1896)^{*}\end{array}$ & $\begin{array}{c}4.800-5.100(+480-660) \\
(6.000-6.375 F)\end{array}$ & $5.640-7.860 \mathrm{M}(7.520-10.480 \mathrm{~F})$ \\
\hline $\begin{array}{l}\text { Professores do } \\
\text { secundário (Prússia)** }\end{array}$ & $2.700-5.100 \mathrm{M}$ & 2.933,35 M (Berlim - 1908) \\
\hline
\end{tabular}

Fontes: Lexis (1897, p. 193)

Notas: *Para a Prússia, trata-se das universidades de Bonn, Breslau, Goettingen, Halle, Koenigsberg (primeiro indice), de Greifswald, Kiel, Marburg e Munster (segundo índice).

As somas entre parênteses representam as indenizações de alojamento, provavelmente integradas nas cifras citadas na tabela, fornecidos por Bornecque (1911). ** Grade de salários dos professores de liceu em 1897, ver Titze (1991, p. 351). Outras colunas: Ver Hohorst, Kocka e

Ritter (1978, p. 109-111), e rendimentos médios de um professor do secundário depois da pesquisa de 1908 do Bureau de statistique impériale (citado em ibid., p. 1/2-I I3, 79 casos).

\section{Tabela 10 - Situação dos professores universitários franceses na hierarquia salarial dos funcionários de médio e alto escalão (em francos correntes)}

\begin{tabular}{lcc}
\hline Categoria & $\mathbf{1 8 9 8}$ & $\mathbf{1 9 0 8}$ \\
\hline Diretor de ministério & 17.000 & \\
Reitor & 15.900 & \\
Inspetor de finanças & $2.000-15.000$ & $2.000-15.000$ \\
Chefe de divisão & 12.710 & \\
\hline
\end{tabular}




\begin{tabular}{lcc}
\hline Categoria & $\mathbf{1 8 9 8}$ & $\mathbf{1 9 0 8}$ \\
\hline Professor de faculdade - Paris & $12.000-15.000$ & $12.000-15.000$ \\
Professor de faculdade - Província & $6.000-11.000$ & $6.000-12.000$ \\
Maître de conférences - Paris & $6.000-10.000$ & \\
Chefe de repartição & 7.985 & \\
Maître de conférences - Interior & $4.500-5.500$ & $4.500-5.500$ \\
Professor agrégél - Interior & $5.500-8.000$ & $5.500-8.000$ \\
Professor não agrégé - Interior & $3.200-5.200$ & $3.200-5.200$ \\
\hline
\end{tabular}

Fontes: 1898 - Recueil des règlements relatifs à l'enseigement secondaire, Paris, Imprimerie nationale, 1900, p. 114 et ss.; Statistique de l'enseigement supérieur 1898, Paris, Imprimerie nationale, 1899; fonctionnaires - remunerações médias da categoria estabelecidos por Turquan (1899, p. 33); 1908: Revue internationale de l'enseigement, tome 55, 1908, p. 520-521 (professores do secundário), tome 56, 1908, p. 143-146 (ensino superior), de acordo com o relatório da comissão extraparlamentar.

Do lado francês, o nível máximo esperado é inferior àquele dos funcionários de alto escalão, como no caso de Berlim: os diretores de ministério recebem, em média, 17.000 francos, os reitores ultrapassam claramente o máximo de remuneração de primeira classe com 15.900 francos, o que explica a atração para essas funçóes na província. Em contrapartida, os professores da Sorbonne de primeira classe equiparam-se aos inspetores gerais de finanças (15.000 francos), e ultrapassam os chefes de divisão, mas eles formam uma pequena minoria do corpo, enquanto que todo inspetor de finanças pode tornarse inspetor geral. Entretanto, é bem mais interessante a comparação com o início da carreira: os maîtres de conférences ${ }^{15}$ do interior estáo distantes (diferentemente dos professores alemães) dos professores do secundário parisiense, de onde advém, em alguns casos, a preferência por um cargo em um liceu da capital ao invés de uma carreira inicial nas pequenas faculdades ${ }^{16}$.

Contudo, a diferença das remuneraçóes citadas não apresenta toda complexidade da situação relativa das diversas categorias. Na verdade, na universidade alemã menos importante é realmente possível ultrapassar

15 Professores pesquisadores concursados que compõem um dos escalões do corpo professoral na França. No século XIX, a designação referia-se mais especificamente àqueles que ministravam cursos em pequenos grupos.

16 Se acrescentássemos, para fins de comparação, os salários de um grande estabelecimento de pesquisa como a EPHE, inferiores aqueles dos cargos universitários no interior, a manutenção da concorrência secundário/ superior seria ainda mais evidente. 
o nível médio graças aos honorários dos estudantes ou a negociação que antecede a nomeação ${ }^{17}$, situação impossível na França. Assim, em Goettingen, em 1896, oito professores da faculdade de filosofia recebem mais de 7.000 marcos, subclassificando, portanto, dezesseis berlinenses homólogos que não ultrapassam 6.700 marcos; nove professores de Bonn e dois de Halle estão no mesmo caso, para nos limitarmos ao reino da Prússia ${ }^{18}$. Se acrescentarmos os honorários dos cursos pagos, alguns professores "provincianos" não tem nada a invejar os berlinenses: três professores em Bonn recebem por esses cursos, quase tanto quanto suas remuneraçóes principais (5.000 marcos ou mais), quatro estão na mesma situação em Breslau, dois em Halle, quatro em Marburg, etc. ${ }^{19}$. Na medida em que a vida é menos cara nessas cidades, em termos de poder de compra, alguns não têm interesse em deixar as universidades menos importantes. Uma descrição do modo de vida dos professores de Bonn, realizada por Edmond Dreyfus-Brisach confirma esse veredito subjacente. "A maior parte dos professores que visitei me pareceram muito confortáveis; muitos entre eles moravam nos melhores bairros da cidade, possuiam belas casas na Coblenzstrasse, na Poppelsdorferallee e na Meckenheimerstrasse." (DREYFUS-BRISACH, 1879, p. 86-87).

Além disso, a diversidade interna dos ganhos dos professores de Berlim é mal traduzida pela diferença ou as médias citadas. Em 1896, entre 44 professores oridinários da faculdade de filosofia, sete ganhavam menos de 5.800 marcos, vinte oito entre 6.000 e 8.500 marcos, e oito mais que 9.000 marcos $^{20}$. A diferença com os professores extraordinários é ainda mais sensível: em Berlim, quatro ganham menos de 2.000 marcos, doze entre 2.000 e 2.800 , e dez entre 3.000 e $3.600^{21}$. Os mais bem pagos náo

17 Para um exemplo dessa negociação que leva a ultrapassar o nivel máximo autorizado pelo Ministério das Finanças, ver o caso excepcional de Wilamowitz quando convidado para ir a Berlin: ele recebe (em 1896) 15.000 marcos, enquanto que o máximo autorizado é de 12.000; é o Imperador que paga a diferença de seus cofres (CALDER; KOSENINA, 1989, p. 121, nota 502).

18 Os professores podem interferir na concorrência entre estados que tem quadros salariais diferenciados: em Saxe, por exemplo, existe apenas uma classe de remuneração, mas ela é superior à remuneração inicial em outros estados: 6.000 a 12.000 marcos, enquanto em Berlin os professores começam com 4.800 marcos (LEXIS, 1897, p. 194).

19 Ibid., p. 196.

20 Ibid., p. 194

21 Ibid., $p .195$ 
alcançam o salário básico dos professores ordinários, diferentemente daquilo que se constata na França, onde há uma sobreposição parcial entre os escalóes salariais das diversas categorias. Em 1908, como mostra a Tabela 10, os maîtres de conférences recebem entre 4.500 e 5.500 francos por ano no interior, e entre 6.000 e 10.000 francos em Paris; os professores, segundo a classe, entre 6.000 e 12.000 francos no interior, e entre 12 e 15.000 francos em Paris.

Precisamente, tanto em Paris como na Alemanha, a base dos debates principais sobre as questóes salariais é a extrema desigualdade da distribuição entre as classes na França, e entre os níveis de remuneração na Prússia. Em 1908, o relatório da comissáo extraparlamentar sobre a reorganização da progressão no ensino superior estabelece que no interior, oito professores sobre dez sejam reagrupados nas classes inferiores (112 sobre $137 \mathrm{em}$ ciências, 116 sobre 141 em letras, 108 sobre 134 em medicina, 132 sobre 161 em direito) e recebam no máximo 8.000 francos. Os três quartos dos professores das faculdades de filosofia na Prússia estão em uma situação idêntica. $\mathrm{O}$ relator da comissão propôe, na França, reduzir essa proporção institucionalizada para 7 sobre $10^{22}$.

Por meio dessa comparação, pode-se concluir, portanto, que os protestos dos universitários franceses referem-se menos aos níveis absolutos das remuneraçóes, comparáveis aos níveis alemães, ou a posição na hierarquia geral da função pública, igualmente análoga, do que a um sentimento de injustiça e de descompasso entre a imagem que fazem de si e o novo ideal contido no processo de reforma. O sentimento de injustiça advém da diferença estrutural entre Paris e o interior, e da desproporção entre as altas e as baixas remuneraçôes. Sem acesso às instituiçóes parisienses, tem-se pouca chance de alcançar o máximo possível, pois a rigidez do sistema de cátedras e de classes conduz a uma progressão muito lenta tanto no interior quanto em Paris ${ }^{23}$.

22 O relatório geral da comissão extraparlamentar citado na Revue internationale de l'enseignement, tomo 56, 1908, p. 6I. Na Prússia, a mesma redução das desigualdades está em debate na época e resulta, em 1909, em uma equiparação dos direitos honorários pagos pelos estudantes a fim de beneficiar os professores mais mal pagos e aqueles com rendimentos adicionais mais baixos (BORNECQUE, 1911, p. 312). As disposições sobre os adicionais variam de acordo com os estados, se bem que, também nesse caso, os professores podem influenciar na concorrência.

23 O reajuste dos anos 1920, para cobrir a inflação da guerra, não modificará esse estado das coisas: o máximo possivel para um professor titular de Paris é fixado, em I de janeiro de 1923, em 28.000 francos, enquanto um professor do interior é limitado a 25.000 francos (Revue internationale de l'enseignement, 1921, tomo 75, p. 390-392). 
Não é necessário, portanto, idealizar o modelo alemão de retribuição que repousa - não devemos esquecer - sobre uma extrema injustiça de base entre os professores ordinários e os professores extraordinários ou privat-docenten. A justificativa para essa dissimetria é a de estabelecer uma retribuição que incentive o avanço da ciência e o avanço pessoal, enquanto que a hierarquia funcional à la française tem tendência a produzir uma conformidade, os rendimentos ligados à posição e a prioridade da antiguidade sobre o talento. $\mathrm{Na}$ Alemanha, igualmente, os professores ordinários que possuem, pela habilitação e pela cooptação, o poder de legitimação dos outros tendem a favorecer o conformismo intelectual e a marginalizar de modo crescente as novas disciplinas e as jovens geraçóes que tem cada vez menos expectativas de ver sua posição melhorar, em decorrência do aumento do número de candidatos. O resultado disso é uma tensão interna crescente que se exprime no movimento dos "nichtordinarien" antes de 1914. Apesar de sua mobilizaçáo, somente chega a resultados positivos com a reorganização por iniciativa do poder político, posterior a guerra (MULLER, 1991). Na França, as tensóes também aumentam nos períodos de conjuntura universitária medíocre, na qual o tempo de promoção se alonga mais, antes de 1968, sem explosão maior por conta de uma escala continua de estágios, e sem as diferenças de casta que separam, como na Alemanha, as diversas categorias. Se as tensóes políticas externas puderam encontrar terreno favorável no interior das universidades alemãs nos anos 1930, foi em razão desse fenômeno das diferenças sociais internas, produtoras de ressentimentos e de ajustes de conta em período de crise. $\mathrm{O}$ mesmo processo de ruptura de consenso se encontra na França, precisamente quando se multiplicam grupos diversos e com diferentes perspectivas de futuro ${ }^{24}$.

$\mathrm{Na}$ Prússia, os projetos de reforma do início do século XX terminaram por reduzir essa individualização dos rendimentos profissionais tanto pelo princípio da antiguidade quanto pelo limite máximo dos honorários e a adoção de um mecanismo redistributivo. A segunda geração sente, então, essa retração mais severamente, a qual se adicionam todos os problemas financeiros nascidos das desregulamentaçóes monetárias dos anos 1920 e a lentidão das carreiras, como vamos ver.

24 Cf. Titze (1990, 1991); Chroust (1993, pp. 61-112) Schwabe (1984). 


\section{As etapas da ascensão}

Para instaurar na França alguns princípios de funcionamento do modelo alemão de universidade, os reformadores universitários estavam conscientes de que duas transformaçóes seriam necessárias. Em primeiro lugar, seria necessário reequilibrar, no interior do sistema, o peso respectivo de Paris e do interior, com o objetivo de garantir um movimento professoral entre as universidades e não somente entre o centro e a periferia. Em segundo lugar, o mecanismo de promoção deveria levar em consideração as capacidades de inovação intelectual possibilitadas pela criação de um vivier de jovens professores liberados dos constrangimentos do ensino secundário e podendo acessar mais cedo as posiçóes de não titulares no ensino superior e na pesquisa: maîtres de conférences, chargés de cours ${ }^{25}$, préparateurs ${ }^{26}$, chefs de travaux et de laboratoire ${ }^{27}$, directeurs d'études ${ }^{28}$ de l'EPHE, etc.

A comparação dos tipos de cargos ocupados, no início da carreira pelos futuros professores da Sorbonne permite determinar se essas inovaçôes preencheram sua função de aproximação com o modelo dos privat-docenten alemães. Com relação a isso, e não é algo muito surpreendente, as faculdades científicas estão muito mais avançadas que as faculdades literárias. Para os professores destas últimas, a passagem pelo ensino secundário, mesmo para os professores nomeados para a Faculdade de Letras de Paris entre 1909 e 1939, permanece majoritária. Ao contrário, em ciências, desde a primeira geração e cada vez mais para a segunda, a divergência entre as carreiras voltadas para o ensino superior e aquelas direcionadas para o secundário se consolida. A existência de uma mobilidade muito mais significativa dos cargos de espera (préparateurs, chefs de travaux, directeurs de laboratoire, chargés de cours), hierarquicamente inferiores e seguidamente menor remunerados que as cátedras de liceu, mas estatutariamente ligados às faculdades ou às instituiçóes de pesquisa explica esta diferenciação profunda dos dois perfis de carreira segundo os grupos disciplinares.

25 Cargo temporário e vinculado estritamente ao ensino (N.T).

26 Normalmente vinculado a uma disciplina ou laboratório, é encarregado da preparação de atividades práticas mais elementares (N.T).

27 Assistente encarregado de funções pedagógicas ou técnicas, subordinado aos chefes de estabelecimento de ensino ou de laboratório (N.T).

28 Professores pesquisadores vinculados a instituições de pesquisa e responsáveis pelo oferecimento de seminários (N.T). 
Tabela II - Localização dos primeiros cargos ocupados pelos professores da Sorbonne (letras e ciências) de acordo com o período de nomeação

\begin{tabular}{lccccc}
\hline & Secundário & $\begin{array}{c}\text { Pesquisa } \\
\text { em Paris }\end{array}$ & $\begin{array}{c}\text { Superior } \\
\text { em Paris }\end{array}$ & $\begin{array}{c}\text { Superior no } \\
\text { interior }\end{array}$ & Outro \\
\hline Letras & & & & & \\
\hline Antes de 1909 & 74,1 & 5,1 & 1,7 & 12 & 6,9 \\
1909-1939 & 75,7 & 1,8 & 2,9 & 17,7 & 1,8 \\
\hline Ciências & & & & & \\
\hline Antes de 1909 & 27,2 & 36,3 & 9 & 22,7 & 4,5 \\
1909-1939 & 21,3 & 40 & 4 & 29,3 & 5,3 \\
\hline
\end{tabular}

Fonte: Elaborada pelo autor.

É necessário, contudo, relativizar essa diferença. De fato, se considerarmos não apenas o primeiro cargo, mas também o cargo seguinte, evidencia-se que aqueles que ambicionam chegar ao topo da pirâmide universitária perceberam bastante rápido, mesmo em letras, que é necessário romper o antigo cordão umbilical com os liceus. Como segunda opção, os futuros professores da Sorbonne, primeiramente nomeados em um liceu de província, optaram, quase todos, no momento de mudança, pelo secundário em Paris, o que lhes permite ao menos trabalhar comodamente em suas teses nas bibliotecas parisienses e se encontrar com seus mestres. Caso já sejam doutores, frequentemente ocupam um cargo no ensino superior no interior ou em Paris, ou encontraram, como seus homólogos cientistas, uma posição de espera de não titular.

Os tempos de espera para acessar as posiçóes mais favoráveis, em uma perspectiva de carreira longa no superior, são evidentemente mais significativos para os literatos do que para os científicos: nesta geração, são necessários, em média, 5,2 anos para sair do secundário no interior, para o secundário parisiense são 9,4 anos, e para o superior no interior, 12 anos. Em ciências, para 75 professores nomeados na Sorbonne depois de 1909, 47 integraram, desde a conclusão de seus estudos, um cargo de ensino superior ou de pesquisa; os outros 28 esperaram não mais que uma média de 5,6 anos, às vezes com algumas interrupçóes, para ocupar cargos 
temporários de pesquisa. Os estágios mais longos que o normal no secundário se explicam, em geral, pela negação em sair de Paris ou por handicaps sociais específicos (origem modesta, rural ou encargos familiares).

A transformação mais interessante entre as duas gerações consideradas reside na modificação das vias mais frequentes, o que marca a extensão nacional do campo universitário. Para a primeira geração, o a carreira típica de um futuro professor da Faculdade de Letras de Paris evitava o ensino superior no interior, mal pago e mal considerado. O vivier dos futuros eleitos era composto dos professores das classes superiores dos liceus parisienses, dos maîtres de conférences da École normale supérieure e dos maîtres de conférences da Sorbonne, cargos obtidos depois de um estágio mais ou menos longo no secundário do interior. Ao contrário, os professores da Faculdade de Letras de Paris nomeados depois de 1909, realizam percursos cada vez mais complexos: do secundário no interior ao superior no interior e ao superior em Paris; do secundário no interior ao secundário em Paris, depois do superior no interior antes do acesso à faculdade de letras, ou enfim, do secundário em Paris ao superior no interior, antes de ingressar na Sorbonne. No primeiro período, as redes estavam concentradas em Paris, considerando todos os tipos de ensino. Para as geraçôes posteriores, a Sorbonne é o ponto de chegada das redes que a conectam ao ensino superior no interior. Entretanto, as chances de acesso ao topo são muito desiguais, variando de acordo com a cidade da universidade de início da carreira. Como vimos, disso derivam os debates a propósito das remuneraçóes, do antagonismo Paris/interior e, também, daquele entre as grandes e pequenas universidades ${ }^{29}$.

Em ciências, a mobilidade e a complicação dos percursos são menores em decorrência da diversificação das posiçôes internas a cada faculdade.

29 O fracasso de todas as proposições para "especializar" as universidades do interior ou hierarquiza-las se explica, certamente, pelas pressões políticas eficazes dos parlamentares locais, mas também pela recusa dos professores que tiveram o azar de iniciar nas pequenas universidades de ter suas possibilidades bloqueadas caso a especialidade que pratica deixe de existir (em ciências), ou seja muito próxima do secundário (em letras). 0 debate teve espaço várias vezes na Revue internationale de l'enseignement: cf. Clédat (1908, p. 122-123), e as respostas em "Enquête sur la spécialisation des facultés des lettres" (Revue internationale de l'enseignement, 1908, p. 340-346 e 416-424; 1909, p. 77-82, 148-161, 238-249 e 363-380). 0 tema é retomado após a guerra por Audollent (1926, p. 129-136). São sempre os professores das pequenas universidades, como de Caen e de Clermont, que são mais reservados, opondo-se aqueles das grandes universidades do Sul, como Bordeaux e Toulouse, que sofrem menos a concorrência parisiense. 
Para aqueles que tiveram a chance, desde o início, de se beneficiar de posiçôes de espera em um estabelecimento superior parisiense, o ponto de bloqueio se situa no nível dos chefes de trabalhos ou de maîtres de conférences. Ao sair do primeiro posto, é fundamental para estes futuros professores do ensino superior ${ }^{30}$ ou ser promovido para uma posição em um estrato intermediário, ou aceitar um deslocamento para o ensino superior do interior, antes do retorno para Paris como maître de conférences, chargé de cours ou, raramente, diretamente como professor.

$\mathrm{O}$ circuito delineado não impede que permaneça, mesmo entre os futuros professores da Faculdade de Ciências de Paris, um grupo minoritário obrigado a ensinar no secundário durante algum tempo, e para os quais a aprendizagem da pesquisa é mais difícil do que para seus colegas. Excluindo os casos de conveniência pessoal ${ }^{31}$, esse tipo de percurso se explica, essencialmente, pelas desvantagens sociais. Nas duas geraçóes, a maioria dentre eles provém de meios menos favorecidos: suas famílias pertencem a pequena burguesia, ou a um meio de classe média sem herança cultural. Seus recursos familiares (financeiros, mas também em termos de cultura e de ambição social) são mais limitados, o que faz com que esses universitários prefiram ocupar os cargos com maior segurança financeira do secundário, do que as funçôes de pesquisa mal pagas. Outra interpretação social complementar é possível: vivendo seu acesso ao cargo de professor de liceu já como uma promoção, não concebem, não imediatamente, a necessidade de adquirir, trabalhando em um laboratório, os títulos necessários para o ensino superior, horizonte social que eles vislumbram somente em um segundo momento, constatando, por exemplo, o sucesso de seus contemporâneos ou a abertura de novos cargos.

Deixando de lado a clivagem social interna e analisando globalmente, a rota em direçáo ao topo deixa menos espaço para o acaso do que nas letras, como demonstram as idades de acesso comparadas ao ensino superior segundo as faculdades (Tabela $12 \mathrm{~A}$ ). Em ciências, chegar ao topo

30 Uma parte desses cientistas aprendizes pode, igualmente, renunciar a essa carreira por cargos na indústria, mas, por definição, isso nos escapa.

31 Estão incluídos nesta rubrica os casos de encargos familiares precoces, o que impede de se contentar com as remunerações menores de preparador, ou a necessidade de permanecer próximo de um familiar em uma região especifica ou em Paris. 
da pirâmide hierárquica supóe uma entrada no ensino superior majoritariamente antes dos 30 anos. Isso é muito menos significativo em letras, onde tanto na primeira geração como na segunda, constata-se uma repartição quase igual entre as duas principais faixas etárias (25-29 anos, e 30-35 anos).

A menor profissionalização das carreiras literárias que se evidencia na diversidade relativa dos tipos de instituições de entrada e na lentidão global do percurso é ainda mais evidente quando comparada com a situação dos futuros professores de Berlim. Ao contrário da situação francesa, em letras e nas ciências, esses estão, em sua maioria, ocupando cargos no ensino superior desde antes dos 30 anos, graças ao sistema de privat-docenten. As entradas mais tardias existem também, mas menos frequentemente que na França, salvo no primeiro período, no qual antigos professores do secundário ainda entram tardiamente no ensino superior.

No total, portanto, as carreiras científicas francesas realizadas em Paris estão fundadas no modo de organização alemão de ruptura com o liceu, enquanto que as carreiras literárias não conseguiram a mesma façanha, como assinala a diferença entre as disciplinas literárias nas duas universidades comparadas.

Tabela 12 A - Repartição de idades de acesso ao ensino superior dos professores da Faculdade de Letras e dos professores da Faculdade de Ciências de Paris (\% na linha)

\begin{tabular}{|c|c|c|c|c|}
\hline Letras & $<25$ anos & $25-29$ anos & $30-35$ anos & 35 anos \\
\hline Antes de 1909 & 10,3 & 36,2 & 31 & 22,4 \\
\hline 1909 ou depois & 5,6 & 26,1 & 35,5 & 4,7 \\
\hline \multicolumn{5}{|l|}{ Ciências } \\
\hline Antes de 1909 & 45,4 & 22,7 & 27,2 & 4,5 \\
\hline 1909 ou depois & 36 & 44 & 13,3 & 6,6 \\
\hline
\end{tabular}


Tabela 12 B - Repartição das idades de acesso ao ensino superior dos professores da Faculdade de Filosofia (letras e ciencias) de Berlim (\% na linha)

\begin{tabular}{lcccc}
\hline Letras & $\mathbf{2 5}$ anos & $\mathbf{2 5 - 2 9}$ anos & $\mathbf{3 0 - 3 5}$ anos & $>$ 35 anos \\
\hline Antes de 1909 & 20,7 & 45,3 & 22,6 & 11,3 \\
1909 ou depois & 1,8 & 58,2 & 30,9 & 9 \\
\hline Ciências & & & & \\
\hline Antes de 1909 & 22,8 & 48,5 & 17,1 & 11,4 \\
1909 ou depois & 7,5 & 57,5 & 25 & 10 \\
\hline
\end{tabular}

Por sua vinculação ao ensino secundário clássico e ao princípio de promoção social contido na manutenção da continuidade entre o secundário e o superior, os professores de letras sofreram, portanto, um adiamento global de profissionalização diante da Alemanha ou das ciências.

Para os membros da amostra estudada, a estrutura diferenciada de acordo com as disciplinas explica, principalmente em letras, a importância da situação geográfica dos cargos ocupados antes do parisiense ambicionado. Além disso, tanto em ciências como em letras, as redes mais ou menos constantes indicam que a descentralizaçáo desejada pelos reformadores fracassou globalmente. Longe de ter diminuído, o papel dominante da elite parisiense foi reforçado pelos novos percursos no interior das faculdades.

\section{O fracasso da descentralização}

O fracasso da descentralização aparece claramente quando apresentamos a tabela do último cargo ocupado no momento da eleiçáo a uma cátedra parisiense. 
Tabela 13 - Localização do último cargo ocupado antes da nomeação como professor titular em Paris

\begin{tabular}{|c|c|c|c|c|c|c|c|}
\hline & $\begin{array}{l}\text { 巳 } \\
\text { 도 } \\
\text { 온 } \\
\text { ڤ }\end{array}$ & 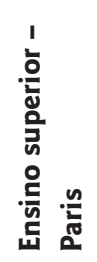 & 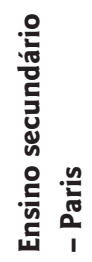 & 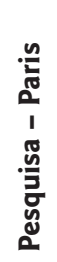 & 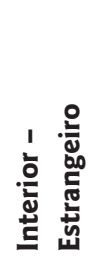 & 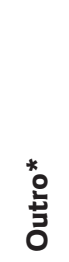 & $\mathbf{z}$ \\
\hline \multicolumn{8}{|l|}{ Letras } \\
\hline $\begin{array}{l}\text { Antes de } \\
1909\end{array}$ & 78,5 & 12,5 & 1,7 & $\mathrm{I}, 7$ & $\mathrm{I}, 7$ & 3,5 & 56 \\
\hline $\begin{array}{l}1909 \text { ou } \\
\text { depois }\end{array}$ & 94,2 & - & - & - & 4,8 & 0,9 & 105 \\
\hline \multicolumn{8}{|l|}{ Ciências } \\
\hline $\begin{array}{l}\text { Antes de } \\
1909\end{array}$ & 75 & 18,1 & - & 2,3 & 4,5 & - & 44 \\
\hline $\begin{array}{l}1909 \text { ou } \\
\text { depois }\end{array}$ & 77,3 & 9,3 & - & 2,3 & 8 & - & 75 \\
\hline
\end{tabular}

Cada vez mais frequentemente, tanto em ciências como em letras, somente chegam ao topo da hierarquia universitária os professores previamente pertencentes às posiçóes inferiores do corpo professoral da Sorbonne, ou aqueles que ocupam cargos imediatamente próximos (Tabela 13): instituiçóes de pesquisa como a EPHE, estabelecimentos de ensino superior como a École Normale Supérieure, aos quais podemos adicionar, em ciências, o Muséum e a Faculdade de Medicina de Paris.

A passagem direta de uma cátedra provincial a uma cátedra parisiense tende a ser excepcional e resultado de circunstâncias particulares. No polo científico, a situação é quase caricatural: entre 1879 e 1908, o único professor eleito, proveniente de uma faculdade provincial e sem passagem por outra instituição em Paris é Albin Haller, titular em Nancy, sucessor de Charles Friedel em 1899. Depois de 1909, uma pequena abertura 
se produz com oito professores do interior que tiveram passagem direta. Em três casos, tratou-se da criação de uma cátedra sobre medida em ciência aplicada, para a qual não existia especialista local para promover: Lucien Marchis é nomeado para a cátedra de aviaçáo fundada pelo mecenato de Basil Zaharoff em 1909, depois de ensinar na Faculdade de Ciências de Bordeaux por 13 anos; Alphonse Mailhe, professor na Faculdade de Ciências de Toulouse, onde fez toda sua carreira, tornou-se o primeiro titular da cátedra de química de combustíveis criada pela cidade de Paris e a Sociedade de Gás de Paris em 1926; ele ocupou ao mesmo tempo a chefia de pesquisas químicas dessa sociedade. Gustave Ribaud, professor em Strasbourg desde 1919, beneficiou-se, em física, da mesma generosidade com sua nomeação para a cátedra de altas temperaturas, fundada igualmente pela Sociedade de Gás de Paris.

$\mathrm{O}$ recrutamento à dominante interne para o topo é acompanhado por uma contrapartida lógica, o fenômeno da fila de espera. Ele aparece por meio da elevação da idade de titulatização entre os dois períodos definidos, tanto no que concerne a idade média quanto às faixas etárias. Tornava-se, assim, necessário equiparar essa espera, sobretudo no segundo período, quando a perenizarão de uma geração que chegou jovem, contemporânea das reformas, e a desigualdade entre as disciplinas agrava o fenômeno em função de acidentes biológicos e das especificidades das pirâmides hierárquicas dos diferentes domínios. Duas soluções foram encontradas: as titularizações ad hominem e a transformação das cátedras por causa da disciplina de origem daquele que tem possibilidade de impor os títulos mais antigos e mais valorizados. As duas soluçóes à rigidez proveniente do centralismo excessivo, entretanto, apenas esvaziam a reivindicação de uma promoção ancorada unicamente em critérios intelectuais, principalmente para o topo ${ }^{32}$.

32 Sobre o caso da história no período entre guerras, Dumoulin (1984, p. 84-103) evidenciou os bloqueios aos quais conduzem esses procedimentos automáticos, frutos de arbitragens cientificas entre comissões de especialistas. 
Tabela 14 A - Repartição de idades de acesso ao cargo de professor ordinário em Berlim (disciplinas literárias e científicas)

\begin{tabular}{|c|c|c|c|c|c|}
\hline Letras & $<35$ anos & $36-45$ anos & $46-51$ anos & $>51$ anos & $\mathbf{N}$ \\
\hline Antes de 1909 & 12,9 & 42,6 & 18,5 & 25,9 & 54 \\
\hline $1909-1939$ & 3,5 & 19,6 & 19,6 & 57,1 & 57 \\
\hline \multicolumn{6}{|l|}{ Ciências } \\
\hline Antes de 1909 & 5,7 & 40 & 40 & 14,2 & 35 \\
\hline $1909-1939$ & 7,7 & 38,4 & 23 & 30,7 & 40 \\
\hline
\end{tabular}

Tabela 14 B - Repartição de idades de acesso ao cargo de professor titular na Faculdade de Letras e na Faculdade de Ciências de Paris

\begin{tabular}{lccccc}
\hline Letras & $<\mathbf{3 5}$ anos & $\mathbf{3 6 - \mathbf { 4 5 } \text { anos }}$ & $\mathbf{4 6 - \mathbf { 5 1 } \text { anos }}$ & $\mathbf{> 5 1}$ anos & $\mathbf{N}$ \\
\hline Antes de 1909 & 1,8 & 32,1 & 33,9 & 32,1 & 56 \\
1909-1939 & - & 5,6 & 29,2 & 65 & 106 \\
\hline Ciências & & & & & \\
\hline Antes de 1909 & 21,9 & 48,7 & 19,5 & 9,8 & 41 \\
1909-1939 & 4 & 17,3 & 32 & 46,6 & 75 \\
\hline
\end{tabular}

A comparação Paris-Berlim é, sobre esse ponto, esclarecedora. A delimitação das vias de acesso do sistema francês estabelece um processo de envelhecimento do corpo dos professores titulares e, sobretudo, um reagrupamento das idades de nomeação em uma distribuição cada vez mais estreita. Por conta das numerosas criaçóes de cátedras, mais de um terço em letras, e a maioria dos professores em ciências, os membros da primeira geração tornam-se titulares antes dos quarenta e seis anos (mais do que a quinta parte, para esses últimos, sendo eleitos antes mesmo dos 35 anos), ao passo que a situação se degrada significativamente depois de 1909 . Ser cinquentenário torna-se a regra e a condição necessária, senão suficiente, para ser cooptado para o topo, para a maioria dos professores em letras, e para quase a metade dos professores em ciências.

Em Berlim, constata-se igualmente uma elevação da idade de acesso ao cargo de professor ordinário por conta do desequilíbrio crescente entre o número de cátedras berlinenses e provinciais, e pela extensão da 
população dos candidatos potenciais, anteriormente referida. No entanto, a maior arbitrariedade e flexibilidade dos percursos permitem ainda carreiras desviantes com relação ao perfil médio, fenômeno excepcional em Paris, exceto em alguns grandes estabelecimentos, não analisados aqui, como o Collège de France ${ }^{33}$.

Aquilo que o exame das etapas de carreira já havia indicado, o alongamento da espera e a complexidade crescente das vias de acesso, é, portanto, reforçado pela análise da etapa final da carreira. O fechamento do grupo de professores da Sorbonne sobre si mesmo, longe de aproximar as carreiras universitárias do ideal alemão, dá um poder crescente aos tropismos centralizadores franceses. As especificidades individuais são cada vez menos consideradas para determinar o sucesso final. Esse julgamento pode parecer excessivo, ou poderíamos lhe opor certo número de exceçóes que escapam a essas regras. No entanto, longe de invalidá-lo, elas acentuam ainda mais as pesadas tendências do sistema francês na medida em que repousam sobre perfis atípicos.

\section{Considerações finais}

As três questóes iniciais postas na abertura deste artigo podem agora receber uma resposta mais precisa. As reformas universitárias, longe de aproximar o status social dos universitários franceses e alemães, mantiveram ou mesmo ampliaram a diferença na medida em que a abertura do recrutamento na França contrasta com o aburguesamento crescente na Alemanha. Membros de uma casta fechada sobre si mesma, apesar das transformaçôes gerais do ensino superior, os professores ordinários berlinenses, produtos de uma antiga sociedade de elites cooptadas, acolhem cada vez menos as demandas tanto dos professores não titulares, quanto dos estudantes de origens mais diversificadas que anteriormente. Membros de um grupo aberto à mobilidade social, os professores da Sorbonne mantêm, ao contrário, em seus escalóes uma minoria ativa suscetível a permanecer receptiva ao ideal do intelectual democrático, mesmo se o

33 Cf. C. Charle (1986, p. 389-424; 1988, p. I6): entre 190I e 1939, 28,3\% dos professores foram nomeados antes dos 45 anos, a porcentagem correspondente depois de 1909 sendo 5,6\% para a Faculdade de Letras e 21,3\% para a Faculdade de Ciências. 
envelhecimento do corpo possa fazer surgir tensôes conservadoras recorrentes e incompreensôes diante dos estudantes mais impacientes que em tempos anteriores a experiência da guerra. Do ponto de vista do funcionamento do sistema universitário, não existe mais, apesar das transferências de experiências estrangeiras e das convergências de funçôes sociais das universidades no período entre-guerras, uma aproximação significativa: a lógica igualitária, centralizadora e gerontocrática é dominante na França, diante de uma lógica aristocrática, decentralizada e menos prisioneira dos critérios formais na Alemanha. As tensões nascidas da exclusão daqueles que não se adequam a essas lógicas são igualmente diferentes. Na França, elas são primeiramente geográficas e, em segundo lugar, geracionais, mas atenuadas pela reorganização dos titulares intermediários. Na Alemanha, elas são ao mesmo tempo sociais e geracionais, sem que as recomposiçóes, mais tardias, possam responder a grande impaciência dos excluídos definitivamente. O consentimento com o nazismo de uma maioria dos professores e o contágio precoce das organizaçóes estudantis, assim como os acertos de contas posteriores a tomada do poder se explicam por essas duas tensóes contraditórias. Para os primeiros, o novo regime vai reestabelecer a autoridade antiga perturbada pelo regime de Weimar, para os segundos, ele vai abrir uma brecha igualitária nos privilégios de casta, e liberar cargos ao perseguir as minorias. Os dois cálculos foram frustrados pelos eventos posteriores, mas mostram a profundidade da crise de identidade de um modelo universitário em descompasso com a sociedade.

A comparação tentada de alguns grandes indicadores definindo os perfis comparados dos professores de duas universidades centrais permite, assim, compreender a partir de dentro a lógica e a evolução dos sistemas universitários dos quais elas são o produto. Além disso, ela informa também sobre a estruturação das elites nos dois países e sobre as meritocracias divergentes que esses professores exemplificam. $\mathrm{O}$ método comparativo tem sido praticado, sobretudo, a partir de grandes agregados estatísticos. A tentativa feita aqui mostra que a microhistória comparada é igualmente frutífera, e permite, mormente, a verificação permanente dos dados, o que desautoriza o trabalho de segunda mão sobre as estatísticas elaboradas por outros. Sem dúvidas, esse método tem a desvantagem de exigir uma longa coleta prévia dos dados, sendo conveniente, portanto, escolher 
cuidadosamente a amostra. Encontramos aqui seus limites intrínsecos para um trabalho realizado individualmente. Somente um grupo de trabalho poderá realizar uma comparação sobre mais de dois países ou sobre diversos grupos de elite. Trata-se de uma perspectiva de trabalho para o futuro.

\section{Referências}

AUDOLLENT, A. Y a-t-il lieu de "spécialiser" et de "moderniser" nos universités provinciales? Revue internationale de l'enseignement, tomo 80, 1926.

BLOTEVOGEL, H. H.. Kulturelle Stadtfunktionen und Urbanisierung. In: TEUTEBERG, H. J. (ed.). Urbanisierung im Industriezeitalter. Köln, Wien: Böhlau Verlag, 1983.

BORNECQUE, H. La situation matérielle et morale des professeurs ordinaires et titulaires des universités d'État dans les différents pays d'Europe. Revue internationale de l'enseignement, tomo $61,1911$.

BOURDIEU, P. Homo academicus. Paris, Éd. Minuit, 1984.

CALDER, W. M.; KOSENINA, A. (ed.). Berufungspolitik innerhalb des Altertumswissenschafts im wilhelminischen PreuBen. Die Briefe Ulrich von Wilamowitz-Moellendorffs and Friedrich Althoff (1883-1908). Frankfurt/Main: Vittorio Klostermann, 1989.

CHARLE, C. Naissance des “intellectuels” (1880-1900). Paris: Éditions de Minuit, 1990a.

À la recherche des bourgeoisies européennes. Le Mouvement social, no 153 , octobredécembre 1990b, pp. 91-97.

. Les professeurs des facultés des sciences (1880-1900), une comparaison Paris-province (18801900)", Revue d'histoire des sciences, XLIII, 4, 1990c, pp. 427-450.

_. Les élites de la République, 1880-1900. Paris: Fayard, 1987 [2006].

Les professeurs au Collège de France (1901-1939), dictionneire biographique. Paris, INRP et Éd. du CNRS, 1988.

_. Le Collège de France. In. NORA, P. (dir). Les Lieux de mémoire. II. La nation. Vol. 3. Paris: Gallimard, 1986.

CHROUST, P. Deutsche Universitäten und Nationalsozialismus, Forschungsstand und eine Fallstudie: Karrieremuster und politische Orientierung der Giessen Professorenschaft (19181945). In. CHARLE, C. KEINER, E. SCHRIEWER, J. (ed.). Sozialer Raum und akademische Kulturen. Studien zur europäischen Hochschullandschaft im 19. und 20. Jahrhundert / À la 
recherche de l'espace universitaire européen. Études sur l'enseignement supérieur aux XIXe et Xxe siècles. Francfort, Peter Lang, 1993.

CLÉDAT, L. La spécialisation des facultés. Revue internationale de l'enseignement, tomo 56, 1908.

DREYFUS-BRISACH, E. L'Université de Bonn et l'enseignement supérieur en Alemagne. Paris: Hachette, 1879.

DUMOULIN, O. Profession “historien”, un métier em crise. Thèse de 3e cycle, EHESS, 1984.

FERBER, C. Von. Die Entwicklung des Lehrkörpers der deutschen Universitäten und Hochschulen 1864-1954. Goettingen: Vandenhoeck et Ruprecht, 1956.

HOHORST, G.; KOCKA, J.; RITTER, G. Sozialgeschichtliches Arbeitsbuch Band II, Materialen zur Statistik des Kaiserreiches 1870-1914. 2. Ed. Munich, Beck, 1978.

JARAUSCH, K. H. Students, Society and Politics in Imperial Germany, The Rise of Academic Illiberalism. Princeton, Princeton U.P., 1982.

—. The Unfree Professions, German Lawyers, Teachers and Engineers, 1900-1950. Oxford: Oxford University Press, 1990.

KOCKA, J (ed.). Burgertum im 19. Jahrhundert. Deutschland im internationalen Vergleich. Munich: DTV, 1988, 3 vol.

_. Les entrepreneurs salariés dans l'industrie allemande à la fin du XIXe et au début du XXe siècle. In LÉVY-LEBOYER, M. (éd.). Le patronat de la seconde industrialisation. Paris: Éd. Ouvrières, 1979

LOT, F. “De la situation faite à l'enseignement supérieur en France " Cahiers de la Quinzaine, 9 et $11^{\mathrm{e}}$ cahier de la $7^{\mathrm{e}}$ série, 1906 , pp. 30-33 et 58-61.

LEXIS, Pr. Die Gehälter und Kollegiengelder der Universitätsprofessoren in Preussen”, Academische Revue, III, janvier $1897, \mathrm{n}^{\circ} 4$.

MULLER, G. Weltpolitische Bildung und Akademische Reform. Carl-Heinrich Beckers Wissenschafts - und Hochschulpolitik 1908-1930. Wien, Köln, Böhlau Verlag, 1991.

NIPPERDEY, Th. Deutsche Geschichte, Arbeitswelt und Burgergeist, 1866-1918. 2. vol. Munich: C. H. Beck, 1991.

RINGER, F. K. The Decline of the German Mandarins. Cambridge (Mass.), Harvard U.P., 1969 [O declínio dos mandarins alemães: a comunidade acadêmica alemã, 1890-1933. São Paulo: Edusp, 2000] 
. Das gesellschaftliche Profil der deutschen Hochschullehrerschaft 1871-1933”. In. SCHWABR, K. (ed.). Hochschullehrer als Elite. Boppard-am-Rhein: Harald Boldt Verlag, 1988.

ROTTLEUTHNER, H. Die gebrochene Burgerlichkeit einer Scheinprofession. Zur Situation der deutschen Richterschaft zu Beginn des 20. Jahrhundert. In. SIEGRIST, H (hg.). Burgerliche Berufen. Göttingen: Vandenhoeck et Ruprecht, 1988.

Revue internationale de l'enseignement. Enquête sur la spécialisation des facultés de lettres, 1909 .

- Tomo 55, 1908.

—. Tomo 56, 1908.

TITZE, H. Der Akademiker-Zyklus. Goettingen, Vandenhoek et Ruprecht, 1990.

Lehrerbildung und Professionalisierung. In. BERG, C. (ed.). Handbuch der deutschen

Bildungsgeschichte, Band IV, 1870-1918. Munich: C. H. Beck, 1991.

SCHWABE, K. (ed.). Hochschullerhrer als Elite. Boppard-am-Rheim: Harald Bold Verlag, 1988.

TURQUAN, V. Essai de recensement des employés et fonctionnaires de l'État. Paris [mimeo], 1899. Disponível no secretariado da Societé d'économie sociale.

WEISZ, G. W. The emergence of modern universities in France (1863-1914). Princeton, Princeton U.P., 1983.

\section{Paris/Berlin: comparative essay between professors of two central universities}

\section{Abstract}

This study juxtaposes a survey of professors teaching in the faculties of Arts, humanites and sciences at the Universities of Paris and Berlin during the same period (1870-1939). It adopts a comparative prosopography to situate these two groups of university elites within their respective settings. The analysis brings to light two distinctive meritocratic models and patterns of change between the university communities through the comparison of changes in the social and geographic origins of professors as well as their branch of study and career patterns. Despite France's centralization and elitist orientation, some social mobility existed, whereas in Germany decentralization and the absence of formal exam procedures continued to favor the same dominant groups over this period. Official attempts to impose the German model in France failed, 
as did the Weimar Republic's attempts to modernize and democratize the academic profession. Between the wars, both the heightened tension and dominant social and political orientation of each group of professors were not, therefore, a product of the period. Rather they reflect the long term structural specificity of each university model and society. Above and beyond its empirical conclusions, this article seeks to valorize the heuristic usefulness of combining a comparative approach with that of social biography for the supranational study of Europe.

Keywords: Paris, Berlin, Comparative prosopography, Professors in humanities and sciences

Recebido em: 27.09.2017

Aprovado em: 11.02 .2018 